症例

\title{
遊離空腸採取後の吻合部を先進部とする小腸腸重積の 1 例
}

\author{
東京慈恵会医科大学外科学講座消化器外科 \\ 小郷 桃子西川勝則湯田匡美 \\ 松本晶小村伸朗矢永勝彦
}

\begin{abstract}
成人腸重積症は稀な疾患で約 $90 \%$ に器質的原因が存在するとされている. 頸部食道癌・ 遊離空腸再建後に発症した腸重積症を経験したので報告する. 症例は78歳の男性. 早期 胃癌 - 食道癌内視鏡的粘膜剥離術後の経過観察中に頸部食道癌が発見され咽頭喉頭食道 切除・遊離空腸再建 + 胃瘻造設術を施行した. 術後 3 日目に嘔吐, 胃㾇より減圧を行っ たが排液が続いた，術後15日目の内視鏡で空腸吻合部に器質的狭窄は認めなかったが, 術後19日目の上部消化管造影で吻合部近傍に通過障害を認め, CTにて同部位にカニ爪 様陰影が確認された. 腸重積症と診断し術後28日目に手術を施行した. 空腸吻合部を先 進部として口側腸管が肛門側に重積していた. 再発を危惧し吻合部を切除・再吻合を行 った，通過障害は改善し再手術後26日目に軽快退院した。遊離空腸採取後の腸重積症は 低頻度であるが, 術後早期の吻合部通過障害を認めた場合, 腸重積症も念頭に置く必要 がある。
\end{abstract}

索引用語：腸重積症, 遊離空腸

はじめに

腸重積症は主に幼少期に発症し, 成人発症の腸重積 症は腸重積症全体の 4 〜 $16 \%$ と比較的稀な疾患であ る. その約 $90 \%$ で腫瘍や炎症などの器質的原因が存在 すると報告されているが，稀に消化管吻合部が原因と なることがある ${ }^{177)}$. 今回，われわれは頸部食道癌に 対する咽頭喉頭食道切除・遊離空腸再建術後に発症し た空腸吻合部を先進部とする腸重積症を経験したの で，文献的考察を加え報告する.

\section{症例}

症例：78歳, 男性.

主訴：嘔吐, 腹部膨満.

家族歴：特記事項なし。

既往歴：高血圧症にて内服加療中.77歳時に早期食 道癌 ( 0 - II a, high grade intraepithelial neoplasia) 胃癌 ( 0 - II c, well differentiated adenocarcinoma, M, ly0, v0, ul-) に対し内視鏡的粘膜下層剥離術 (ESD) 施行. その他, 左突発性難聴・脊柱管狭窄症- 右白内障.

2013年 4 月 9 日受付 2014 年 8 月 20 日採用

〈所属施設住所〉

厂105-8471 東京都港区西新橋 3-19-18
現病歴：2012年 4 月，上部消化管内視鏡検査にて頸 部表在食道癌（cT1b (SM), N0, M0, Stage I )を 指摘された. 2012年 5 月に頸部食道癌に対し, 当院耳 鼻咽喉科 · 形成外科 ·消化管外科にて咽頭喉頭頸部食 道摘出 + 遊離空腸再建 + 甲状腺左葉切除 + 両側頸部り ンパ節郭清, 胃㾞造設術が施行された. 術後 3 日目に 嘔吐を伴う腹部膨満を認め, 胃瘦より減圧を行った。 術後 4 日目と10日目に撮影した腹部単純レントゲンで は, 胃泡の拡張を認めるものの明らかな小腸ガスは認 められなかった（Fig. 1)。胃瘦からの排液が連日500 $\sim 1,000 \mathrm{ml}$ 続くため術後 15 日目に小腸内視鏡検查を施 行したが, 空腸吻合部に虚血性変化・縫合不全は認め ず，ファイバーの通過は容易であった（Fig. 2)。そ の後も排液量の減少が見られないため術後19日目に透 視下に上部消化管造影検査を行ったところ, 十二指腸 水平脚〜空腸起始部に造影剂の停滞と腸管拡張を認 め, その先の吻合部付近で狭小化し, 同部が通過障害 の原因と判断した. 同日施行した腹部単純 CT 検査に おいて上部消化管造影検査と同様に十二指腸～上部空 腸の拡張を認め, その先の狭窄部には小腸のカニ爪様 陰影が確認された（Fig. 3).

上記所見より小腸腸重積症と診断し，これ以上の保 

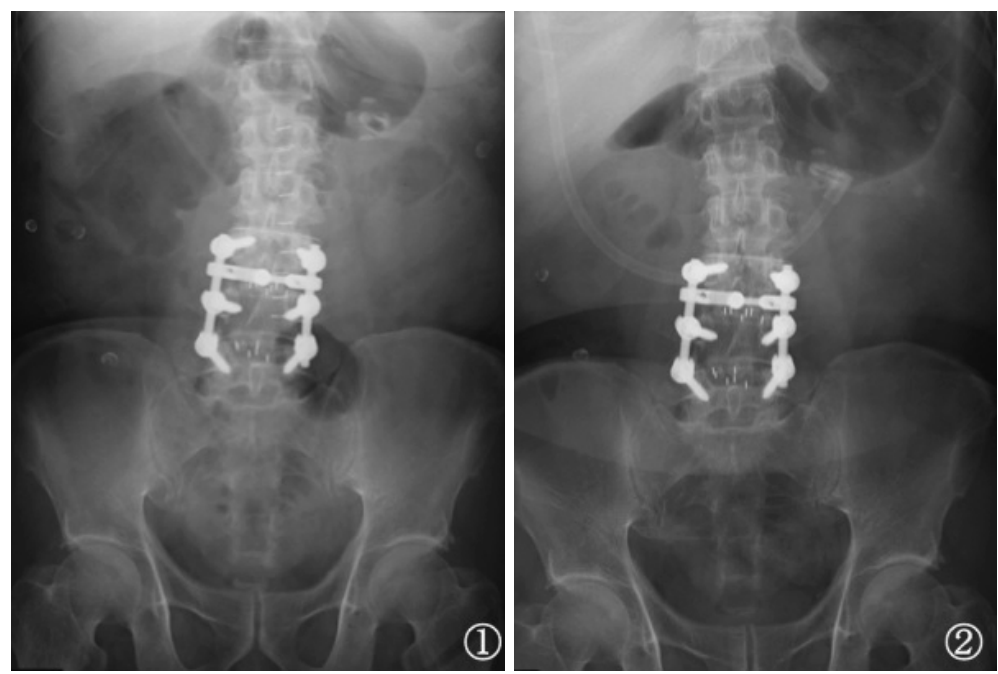

Fig. 1 腹部単純レントゲン写真 : 術後 4 日目（1)，10日目（2) ともに胃泡の 拡張を認めたが, 明らかな小腸ガス像は認めなかった。

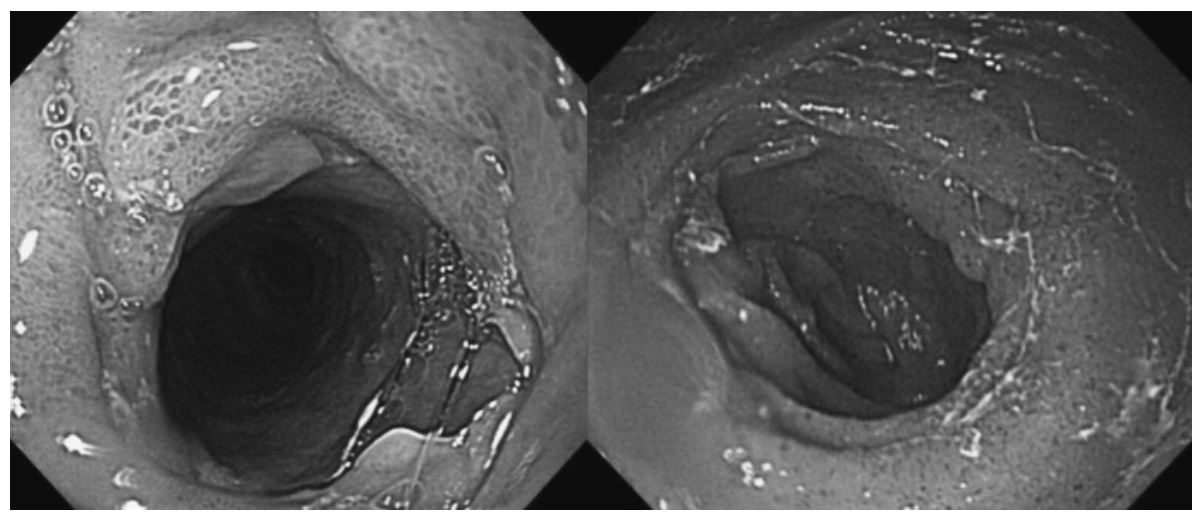

Fig. 2 小腸内視鏡検査（術後15日目）：空腸吻合部に虚血性変化・縫合不全はみられず，ファイ バーの通過は容易であった。

存的加療は困難と考え, 術後28日目に再手術を施行し た。

手術所見 : 初回手術時と同様の上腹部正中切開で開 腹した. 腹腔内の癒着は軽度であった. 腹腔内を検索 したところ，遊離空腸採取後の空腸吻合部を先進部と して口側腸管が肚門側腸管に 3 重に重積していた。 側腸管はTreitz 鞀帯近傍まで軽度拡張し浮腫性変化 を伴っていた，重積腸管はHutchinson 手技にて容易 に整復が可能であった，整復後の腸管は吻合部を含め 内腔は保たれており, 色調は良好で虚血性変化や縫合 不全は認められなかった。 今後の再発の可能性を考慮
し, 空腸吻合部を含めた空腸を約 $10 \mathrm{~cm}$ 切除し, 機能 的端々吻合で再吻合した (Fig. 4).

術後経過：通過障害は改善し, 再手術後26日目に軽 快退院となった. 術後 9 力月の現在, 腸重積症の再発 やイレウス症状を認めない.

\section{考察}

医学中央雑誌にて“遊離空腸”“腸重積”をキーワー ドに検索し，本症例と合わせて考察した，自験例を含 む 6 例の集計を Table 1に示す．年齢は38〜 76歳（中 央值61.2歳）で自験例は中央值に比してょり年長であ った．原疾患は頸部食道癌・下咽頭癌それぞれ 3 例ず 


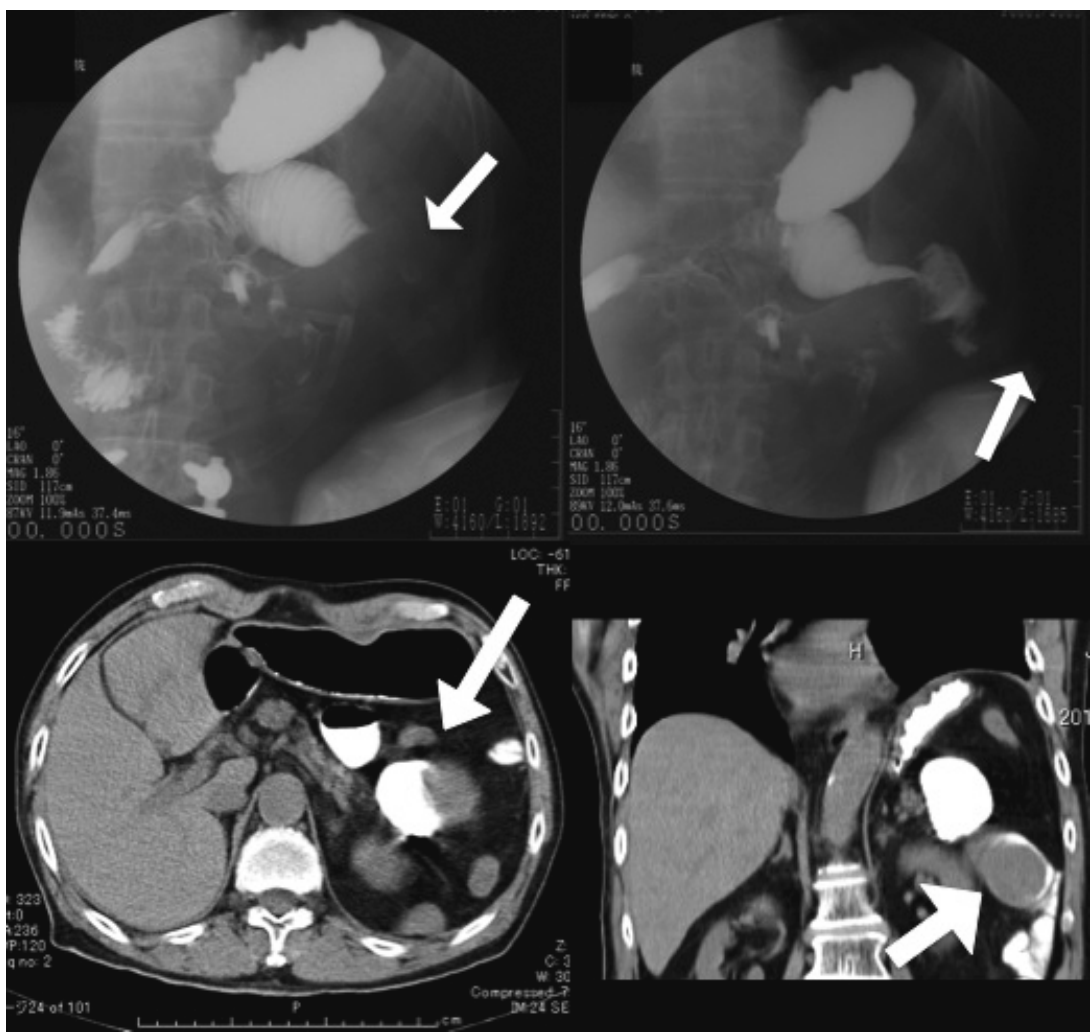

Fig. 3 上部消化管造影検查（術後19日目）/腹部単純 CT 検査（術後19日目，上部消化管 造影検査後）：十二指腸水平脚から空腸起始部にかけて造影剤のうっ滞を認めた。同部 位（矢印）での空腸の狭小化と通過障害が確認された. CTでは十二指腸から上部空腸 にかけて拡張を認め, その先の狭窄部（矢印）にカニ爪様陰影を認めた。

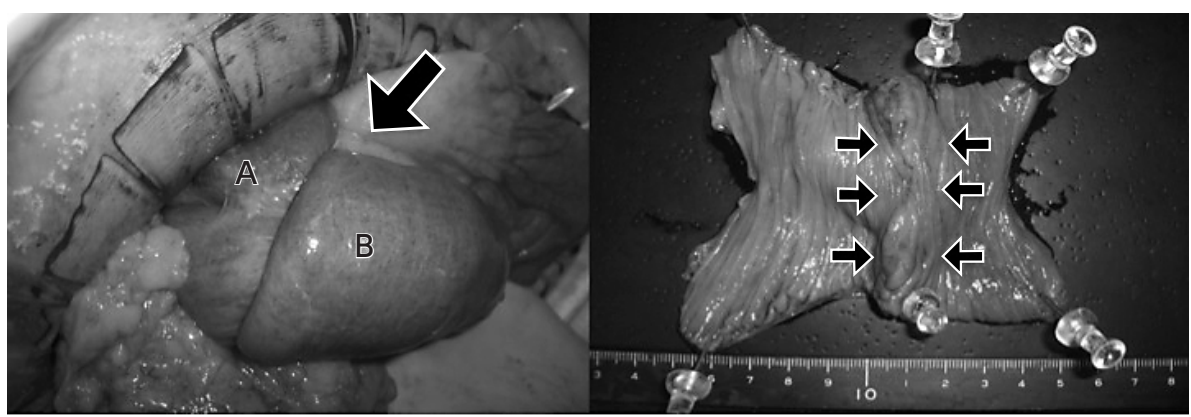

Fig. 4 術中写真/検体標本：口側腸管（A）が矢印の部位で肛門側腸管（B）に重積していた. 吻合部には虚血性変化・縫合不全は認めなかった.

つであった，原疾患に対して全例，咽頭喉頭頸部食道 摘出 +遊離空腸再建が行われていた，遊離空腸の採取 部位は第 2 空腸動脈支配領域 3 例，第 3 空腸動脈支配 領域 3 例であった。腸管吻合は全例 Albert-Lembert
（AL）吻合で施行されていた．腸重積症の発症時期は 全例術後30日以内（1２7日）であり，いずれも開腹 再手術による治療を要していた．また， 6 例中 5 例に 空腸吻合部切除が併施されていた (Table 1) ${ }^{213)}$. 
Table 1 遊離空腸採取後の腸重積症の本邦報告例

\begin{tabular}{|c|c|c|c|c|c|c|c|c|c|c|c|}
\hline 年 & 発表者 & $\begin{array}{l}\text { 年齢 } \\
\text { (歳) }\end{array}$ & 性別 & 原疾患 & 初回手術 & $\begin{array}{c}\text { 空腸採取部位 } \\
\text { (空腸動脈支配領域) }\end{array}$ & $\begin{array}{c}\text { 空腸吻合 } \\
\text { (初回) }\end{array}$ & $\begin{array}{c}\text { 発症時期 } \\
\text { (術後) }\end{array}$ & $\begin{array}{c}\text { 発症から再手術 } \\
\text { までの日数 }\end{array}$ & 吻合部切除 & 再吻合法 \\
\hline \multirow[t]{4}{*}{1993} & 大村ら ${ }^{2)}$ & 76 & $\mathrm{~F}$ & 頸部食道癌 & & 第 2 & \multirow{6}{*}{$\begin{array}{c}\text { Albert- } \\
\text { Lembert } \\
\text { 吻合 }\end{array}$} & 1日 & 19日 & あり & $\mathrm{AL} /$ 側々 \\
\hline & & 64 & M & 下咽頭癌 & & 第 3 & & 25日 & 3日 & なし & なし \\
\hline & & 38 & M & 頸部食道癌 | & 咽頭喉頭食道切除 & 第 2 & & 7日 & 83日 & あり & 層々/端々 \\
\hline & & 53 & $\mathrm{~F}$ & 下咽頭癌 & +遊離空腸再建 & 第 3 & & 17日 & 2日 & あり & 層々/端々 \\
\hline 2007 & 川崎ら ${ }^{3)}$ & 75 & $\mathrm{~F}$ & 下咽頭癌 & & 第 3 & & 27日 & 21日 & あり & FEEA* \\
\hline 2012 & 自験例 & 78 & M & 頸部食道癌 & & 第 2 & & 3日 & 25日 & あり & FEEA* \\
\hline
\end{tabular}

FEEA* $^{*}$ : 機能的端々吻合 (functional end-to-end anastomosis).

腸重積症の多くは幼少期に発症し, 成人発症例は全 体の $4 \sim 16 \%$ とされている. 成人腸重積症は多くの場 合, 腸閉塞との診断で手術に至り, 術中所見にて腸重 積症が発見されることが多い. 腸重積症には回腸一結 腸 (回盲部) ・結腸同士・小腸同士の場合があるが, 回盲部腸重積症ではバウヒン弁の機能障害の関連が示 唆されている ${ }^{6)}$. また, 結腸腸重積症では悪性腫瘍に よるものが多くを占めている. 術後の小腸腸重積症で は腸管癒着・腹壁への癒着が発症誘因と推測される ${ }^{8)}$ が, 本症例では腹垫内癒着は軽度であった，成人腸重 積症の約 $90 \%$ には器質的疾患があるとされており, 術

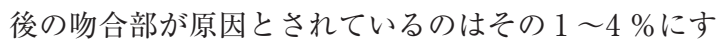
ぎない114).

一般に, 遊離空腸採取の際には第 2 または第 3 空腸 動脈支配領域より空腸を採取することが多い.このた め, 空腸吻合部がTreitz鞁帯の近傍に位置すること になり, 腸管の非協調運動を引き起こすことが腸重積 症の発症に起因すると推測される ${ }^{2}$. また, 検索した 5 症例が全て初回手術時に AL吻合を用いている一方 で, 空腸吻合を機能的端々吻合や層々縫合で吻合した 場合に腸重積症の発症がなくなったとの報告もあるこ とから, 吻合部の浮腫や吻合自体の厚みが腸重積症を 引き起こすとも考えられている5)。遊離空腸採取術後 の早期に嘔吐・腸閉塞症状を認めた場合には腸重積症 も念頭に置く必要があり, その場合は用手整復や罹患 腸管の切除が必要となる. 腸重積症予防の対策として 遊離空腸採取時には機能的端々吻合を用いることが有 効であると考える. 2009年から本症例まで15例の遊離 空腸片採取が行われ，腸重積をきたしたのは本症例の みであった. 本症例以降, 当院での遊離空腸片採取の 際にはFEEAで吻合することが標準となっている. (腹腔内癒着が強く吻合に十分な空腸が確保できない
等の場合は除く.）本症例では, 腸重積症の診断が容 易でなく，発症から再手術まで25日を要したが，責任 病変の口側に造設した胃瘦から減圧が可能であり, 経 鼻胃管を挿入することなく患者のストレスを軽減する ことが可能であった，胃瘦の先端は空腸内まで挿入さ れて扮らず，責任病変には影響しなかったと考えてい る. 咽頭喉頭食道切除における遊離空腸採取時には術 後早期の栄養管理のみならず，術後吻合部トラブルが 発生する可能性があることからも胃㾞造設の有用性が 示唆された。

\section{結 語}

遊離空腸採取後に発症した成人腸重積症を経験し た，遊離空腸採取後の早期に嘔吐・腸閉塞症状を認め た場合には腸重積症も念頭に置く必要がある.

\section{文献}

1）疋島 寬, 川浦幸光, 大村健二他：成人腸重積症 の検討. 外科診療 $1990 ; 32: 1294-1298$

2）大村健二, 金平永二, 石田文生他：遊離空腸片採 取後に発生した腸重積症の 4 例. 日消外会誌 $1993 ; 26: 2879-2882$

3）川崎健太郎, 黒田大介, 白川幸代他：遊離空腸採 取後の吻合部を先進部とする腸重積の 1 例。臨外 $2007 ; 62: 263-266$

4) 尾崎行男, 牧野正人, 池口正英他: 術後腸重積症 の検討. 外科診療 $1982 ; 24: 352-354$

5）大村健二, 浦山 博, 宗本義則他：下咽頭頸部食 道癌に対する咽頭喉頭頸部食道切除術の検討一遊 離空腸移植による頸部食道再建一, 日消外会誌 $1992 ; 25: 967-971$

6）土田 敬, 舩木芳則, 永里 敦他：成人腸重積症 7 例の検討. 臨外 $1992 ; 47: 941-944$

7) Agha FP : Intussusception in adults. AJR Am J Roentgenol $1986 ; 146: 527-531$

8) Azar T, Berger DL : Adult Intussusception. Ann Surg $1997 ; 226: 134-138$ 


\title{
JEJUNAL INTUSSUSCEPTION AFTER HARVESTING A FREE JEJUNAL AUTOGRAFT -A CASE REPORT-
}

\author{
Momoko KOGO, Katsunori NISHIKAWA, Masami YUDA, Akira MATSUMOTO, \\ Nobuo OMURA and Katsuhiko YANAGA \\ Department of Surgery, The Jikei University School of Medicine
}

Intussusception in adults is a relatively rare disease, which is attributed to organic causes in $90 \%$ of the cases. We present herein a case of adult intussusception following harvesting of a free jejunal autograft. A 78-year-old man had undergone endoscopic submucosal dissection (ESD) for the treatment of early gastric and esophageal cancer. One year after ESD, the patient was diagnosed with upper esophageal carcinoma, for which pharyngolaryngoesophagectomy was performed. To restore esophageal continuity, a free jejunal autograft was harvested, and gastrostomy was performed. On the third postoperative day, the patient started vomiting. A gastric drainage via the gastrostomy was initiated; however, the amount of discharge did not decrease. On the 15th postoperative day, gastrointestinal fiberscopy was performed, but failed to show organic stenosis. However, the upper gastrointestinal series and computed tomography performed on the 19th postoperative day, showed stenosis of the jejunal anastomosis. Finally, a diagnosis of intussusception was made, and a reoperation was performed on the 28th postoperative day.

Intraoperatively, the proximal jejunum was revealed to intussuscept through the anastomosis to the distal jejunum. To avoid repetitive intussusception, the anastomotic region was excised, and the reconstruction was performed via functional end-to-end anastomosis. Stasis improved, and the patient was discharged on the 26th day post reoperation.

Intussusception should be considered as a potential cause of intestinal obstruction around the anastomotic region.

Key words : jejunal intussusception, jejunal autograft 